\title{
Differentiation of Vibrio spp. including Core Group Species by PCR-RFLP
}

\author{
Jin-Sook Park*
}

Department of Biotechnology, Hannam University, Daejeon 305-811, Korea

Received January 11, 2012 /Revised February 20, 2012 /Accepted February 23, 2012

\begin{abstract}
The $16 \mathrm{~S}$ rDNA - RFLP types for six Vibrio species ( $V$. fluvialis, V. proteolyticus, V. vulnificus, V. mimicus) including two core group members, $V$. alginolyticus and $V$. parahaemolyticus, and Grimontia (Vibrio) hollisae were determined using PCR-RFLP analysis. Six tetrameric restriction enzymes $(A l u \mathrm{I}, C f o \mathrm{I}$, Dde I , HaelI, Msp I , and Rsa I) were selected for RFLP analysis. V. alginolyticus, V. parahaemolyticus, and $V$. proteolyticus showed the same RFLP pattern following digestion with four of the six used restriction enzymes: Cfo I , DdeI , MspI , and Rsa I . Various restriction enzyme combinations generated digests recognizable as distinct RFLP types for each of the assayed Vibrio species. In particular, Alu I single digestion produced species specific band patterns that enabled the differentiation between these Vibrio species. Dendrogram based on restriction patterns showed that two Vibrio core group members, $V$. alginolyticus and $V$. parahaemolyticus were closely related having a similarity over $90 \%$. Although the observed RFLP pattern for Grimontia hollisae shared several common bands with other Vibrio spp., G. hollisae results were still clearly distinct from Vibrio spp. RFLP types for all restriction enzymes tested. If restriction enzymes are aptly selected, PCR-RFLP analysis is still a rapid and effective tool for differentiating Vibrio species.
\end{abstract}

Key words : $16 \mathrm{~S}$ rDNA, core group, PCR-RFLP, Vibrio

\section{서 론}

Vibrio속의 세균은 그람 음성의 비브리오형 간균으로 하 구, 해양 환경에 널리 분포하며 사람 혹은 어류 등에 병원성 을 나타내는 세균으로 $[3,18]$ 신속한 동정이 매우 중요한 세균 그룹이다. 그러나 이 그룹 내의 종들은 표현형과 유전형이 매우 유사하여 정확한 종 수준의 동정이 매우 어려운 것으로 알려져 있다[7]. 특히 6 개의 Vibrio 종으로 구성되는 Vibrio속 의 core group ( $V$. alginolyticus, $V$. parahaemolyticus, $V$. harvey, $V$. campbellii, $V$. rotiferianus, 그리고 $V$. natriegens)은 $16 \mathrm{~S}$ rRNA gene의 유사도가 $97.6 \%$ 이상, DNA-DNA 상동치 (reassociation value)는 $70 \%$ 에 가까운 값을 나타내는 매우 밀접한 유연관계를 갖는 세균 종들로 구성되는데 $[2,13]$ 이들 을 중심으로 ARDRA, RADP, RFLP, AFLP, IGS-PCR, ribotyping 등 여러 가지 분자적 방법들을 이용하여 Vibrio 종의 동정 및 검출이 시도되었으나 적용하는 방법에 따라 동정의 결과가 다른 것으로 보고되었다 $[3,13,18]$. 또한 $16 \mathrm{~S} \mathrm{rRNA}$ gene의 염기서열을 이용한 Vibrio 종의 동정에는 한계가 있 는 것으로 보고됨에 따라[4,13], recA [15], rpoB [7] rpos [8], elastase gene [11], $h s p 60$ [12] 등 많은 분자생물학적 방법과 유전자들이 이들 세균 종의 동정에 이용되고 있다. 즉 Vibrio 속 세균의 동정에 다양한 분자유전학적 방법들이 적용되어

*Corresponding author

Tel : +82-42-629-8771, Fax : +82-42-629-8769

E-mail : jspark@hnu.kr
왔으며 그 결과 Vibrio 속 분류 체계는 많은 변화를 겪어왔다 [13](http://www.taxivibrio.ilncc.br).

최근 세균의 종을 규정하는 위원회(hoc committee)에서는 DNA-DNA reassociation 대신 MLSA (multilocus sequence analysis)를 이용하는 것을 권고하고 있다. MLSA는 흔히 다 섯 종류 이상의 여러 관리 유전자(housekeeping genes), 예를 들어 $16 \mathrm{~S} r \mathrm{rNA}, r p o \mathrm{~A}, r e c \mathrm{~A}, p y \mathrm{H}, r p d \mathrm{~B}, r p \mathrm{D}, g y \mathrm{~B}, r c \mathrm{~B}, t o x \mathrm{R}$, 등의 유전자의 염기서열 차이를 이용하여 분류군 간의 유연관 계를 분석하는 방법으로 최근 Pascual 등[13]은 MLSA를 수행 하여 DNA-DNA reassociation 값과의 비교를 통하여 Vibrio core group의 동정에 대한 유용성을 평가하였다.

한편 제한효소를 이용한 RFLP (restriction fragment length polymorphism) 분석은 genetic fingerprinting의 한 종류로 실험과정이 매우 단순하고 신속하며 적은 양의 $\mathrm{DNA}$ 를 요구하기 때문에 종의 동정, 역학조사 등 세균의 분 류학적 연구에 이용되고 있다[19,20,21]. 또한 PCR을 이용하 여 $16 \mathrm{~S}$ rRNA gene을 비롯한 특정 유전자의 증폭이 용이해 지면서 PCR-RFLP 방법을 이용한 연구가 널리 수행되고 있 다. $16 \mathrm{~S}$ rRNA gene과 같은 특정 유전자의 제한효소패턴 (restriction pattern)은 사용하는 제한효소의 종류에 따라 종 (species)과 속의 구분이 가능하며, 높은 재현성을 나타내는 것으로 알려져 있다[5,19,20]. 한편, 종의 구분에 있어 변별력 이 낮은 것으로 평가되는 경우도 있다[18]. 따라서 본 실험 에서는 Vibrio core group에 속하는 V. alginolyticus와 $V$. parahaemolyticus, 2종을 포함하여 V. proteolyticus, V. vulnifi- 
cus, V. Aluvials, V. mimicus 총 6 종의 Vibrio 균주와 참고 균 주로 최근 Vibrio속에서 Grimontia속으로 옮겨진[16] Grimontia hollisae를 대상으로 6 종(Alu I, Cfo I, Dde I, Hae III, $M s p \mathrm{I}, R s a \mathrm{I})$ 의 제한효소를 이용한 RFLP 패턴 분석을 실시하여 Vibrio속 세균의 동정에 대한 $16 \mathrm{~S} \mathrm{rDNA}-\mathrm{RFLP}$ 의 유용성을 재평가하고자 하였다.

\section{재료 및 방법}

사용 균주 및 배지

본 실험에서 사용한 균주는 모두 표준 균주(Type strain)로 V. alginolyticus $\mathrm{KCTC}^{2} 472^{\mathrm{T}}$ (=ATCC17749 ${ }^{\mathrm{T}}$ )와 $V$. fluvialis $\mathrm{KCTC}_{2473^{\mathrm{T}}}$ (=ATCC33809 ${ }^{\mathrm{T}}$ 는 한국 유전자은행(Korea Collection for Type Clutures, Korea Research Institute of Bioscience and Biotechnology, Daejon, Korea)에서, V. parahaemolyticus $\mathrm{ATCC} 17802^{\mathrm{T}}, V$. proteolyticus ATCC15338 ${ }^{\mathrm{T}}, \quad$ V. vulnificus ATCC27562 ${ }^{\mathrm{T}}$, V. mimicus ATCC $33653^{\mathrm{T}}$, Grimontia hollisae ATCC $33564^{\mathrm{T}}$ 는 ATCC (American Type Cultrue Collection, Rockville, MD. USA)로부터 분양 받았으며 균주는 $\mathrm{MB}$ (Marine Broth, Difco, Detroit, USA) 배지를 이용하여 $30^{\circ} \mathrm{C}$ 에 서 1-2일간 배양하여 DNA 추출에 사용하였다.

\section{DNA추출 및 $16 \mathrm{~S} \mathrm{rDNA}$ 의 PCR증폭}

염색체 DNA는 배양된 세균 균주의 각 colony로부터 gDNA extraction kit (Solgent, Korea)를 사용하여 분리하였 으며 분리된 $\mathrm{DNA}$ 를 $\mathrm{PCR}$ 반응의 주형으로 사용하였다. $16 \mathrm{~S}$ rDNA의 증폭에는 27f (5'-AGA GTT TGA TCC TGG CTC AG-3')와 1492r ( $5^{\prime}$-TAC GGY TAC CTT GTT ACG AC-3')의 primer 쌍을 사용하였다. 최종 반응량 $100 \mu 1$ 가 되도록 10 $\mathrm{mM}$ Tris- $\mathrm{HCl}$ (pH8.3), $1.5 \mathrm{mM} \mathrm{MgCl} 2,50 \mathrm{mM} \mathrm{KCl}, 100 \mu \mathrm{g}$ gelatin/ml, $200 \mu \mathrm{M} \mathrm{dNTP}$, 각 oligonucleotide primer 200 nM, $2.5 \mathrm{U}$ 의 Taq polymerase (Takara, Japan), $100 \mathrm{ng}$ 의 주형 DNA를 혼합하여 PCR 반응을 수행하였다. Perkin-Elmer DNA thermocycler (DNA thermal cycler 480, Perkin-Elmer Co., USA)를 이용하여 $94^{\circ} \mathrm{C}$ 에서 3 분간 초기 변성시킨 후, $94^{\circ} \mathrm{C}$ 에서 1 분간 변성, $60^{\circ} \mathrm{C}$ 에서 1 분간 냉각, $72^{\circ} \mathrm{C}$ 에서 2 분 간 신장, 이 과정을 $30 \mathrm{cycle}$ 반복 수행한 후 최종적으로 $72^{\circ} \mathrm{C}$ 에서 7 분간 신장시켰다. 증폭된 $\mathrm{DNA}$ 의 확인을 위해서 $\mathrm{PCR}$ 반응액 $3 \mu 1$ 를 취하여 1\% agarose gel (Bio-Rad, USA)을 이용 하여 Mupid-ex (ADVANCE, Japan)로 $100 \mathrm{~V}, 25$ 분간 $1 \mathrm{x}$ TAE buffer (40 mM Tris-acetate, $1 \mathrm{mM}$ EDTA, $\mathrm{pH}$ 8.0)에서 전기영동 후, ethidium bromide $(\mathrm{EtBr}, 50 \mathrm{ng} / \mathrm{ml})$ 에 10 분간 염색하여 $\mathrm{UV}$ 하에서 $1.5 \mathrm{~kb}$ 의 DNA 단편을 확인하였다. 증폭 된 DNA의 크기를 측정하기 위한 marker로는 $1 \mathrm{~Kb}$ ladder를 사용하였다.

\section{RFLP 분석 및 덴드로그램 작성}

$\mathrm{PCR}$ 산물의 RFLP 분석을 위해 4 base를 인식하는 $A l u \mathrm{I}$, CfoI , DdeI , Haell, MspI , Rsa I , 6 종의 제한효소(TaKaRa, Japan)를 사용하였다. 제한효소의 처리는 PCR 산물 $15 \mu \mathrm{l}$, 제 한효소 2 units, 10x reaction buffer $2 \mu 1$ 를 첨가하여 최종 20 $\mu \mathrm{l}$ 로 하여 $37^{\circ} \mathrm{C}$ 에서 4 시간 반응시켰다. $6 \mathrm{x}$ tracking dye와 혼 합하여 $13 \mu \mathrm{l}$ 를 3\% NuSieve agarose (FMC Bioproducts, Rockland, ME, USA)에 loading하여, 0.5x TBE buffer에서 80 $\mathrm{V}$ 로 4 시간 전기 영동한 후 $\mathrm{EtBr}(50 \mathrm{ng} / \mathrm{ml})$ 로 염색하고 Gel Logic 200 (Kodak, USA)을 이용하여 UV 하에서 관찰하여 각 균주의 밴드패턴을 확인하였다.

RFLP type의 패턴 분석을 위해 FPQuest ${ }^{\mathrm{TM}}$ (Bio-Rad, Belgium) software를 이용하였으며 Similarity coefficient는 Dice 방법에 의해 구하고 덴드로그램은 Neighbor-joining에 의해 작성하였다.

\section{결 과}

\section{RFLP 분석}

Vibrio 종 동정에 대한 $16 \mathrm{~S} \mathrm{rDNA}$ 의 PCR-RFLP방법을 평가 하기 위해 core group으로 알려진 $V$. alginolyticus 와 V. parahaemolyticus를 포함하여 6 종의 Vibrio 표준 균주와 참고 균주 Grimontia(Vibrio) hollisae를 대상으로 하였다. 6 종의 제한효소 를 이용하여 생성된 제한효소패턴에 근거하여(Fig. 1) $16 \mathrm{~S}$ rDNA의 RFLP type을 분석하였다. Vibrio의 RFLP type은 각 각 $A l u \mathrm{I}$ 를 이용한 경우 6 개, $C f o \mathrm{I}, 2$ 개, DdeI , 3 개, Haell, 5 개, $M S p I, 2$ 개, RsaI, 3 개의 type이 관찰되었다(Table 1). 6 종의 Vibrio 종, 즉 $V$. alginolyticus $V$. parahaemolyticus, $V$. proteolyticus, $V$. vulnificus, V. Aluviali, V. mimicus 에 대한 6 종류의 효소를 이용한 제한효소패턴을 조합한 결과 총 6 개의 서로 다른 RFLP type (a-f)이 구분되었다(Table 1).

$A l u \mathrm{I}$ 를 이용한 경우 실험한 6종의 Vibrio 종에 대하여 서로 다른 6개의 RFLP type (1-6)이 관찰되었다(Table 1, Fig. 1A).

참고 균주로 사용한 Grimontia hollisae의 경우, 본 실험에서 사용한 모든 제한 효소에서 Vibrio종의 그것과는 확연히 구분 되는 RFLP type을 나타내었다(Table 1, Fig. 1).

\section{덴드로그램 작성}

6종의 제한 효소를 이용한 Vibrio종의 RFLP 분석을 위해 FPQuest ${ }^{\mathrm{TM}}$ (Bio-Rad, Belgium) software를 이용하여 덴드로 그램을 작성한 결과 Vibrio core group으로 알려진 V. alginolyticus 와 V. parahaemolyticus는 similarity $90 \%$ 이상에서 1 개의 cluster로 구분되었으며, $85 \%$ 이상 유사도에서는 V. proteolyticus와 V. vulnificus를 포함하여 하나의 cluster를 형성하였다. V. fluvialis 및 V. mimicus는 $60 \%$ 이상에서 다른 Vibrio 세균 
Table 1. Bacterial strains used in this study and RFLP fingerprinting types obtained from RFLP analysis of 16S rDNA

\begin{tabular}{|c|c|c|c|c|c|c|c|c|}
\hline \multirow{2}{*}{ Taxon } & \multirow{2}{*}{ Strain } & \multirow{2}{*}{$\begin{array}{l}\text { 16S rDNA } \\
\text { RFLP type }\end{array}$} & \multicolumn{6}{|c|}{ Restriction patterns of $16 \mathrm{~S}$ rDNA digested with: } \\
\hline & & & $A l u \mathrm{I}$ & CfoI & Dde I & Haell & $M s p \mathrm{I}$ & Rsa I \\
\hline Vibrio alginolyticus & KCTC2472 ${ }^{\mathrm{T}}$ & $a^{*}$ & $1^{*}$ & 1 & 1 & 1 & 1 & 1 \\
\hline Vibrio parahaemolyticus & ATCC17802 ${ }^{\mathrm{T}}$ & $\mathrm{b}$ & 2 & 1 & 1 & 2 & 1 & 1 \\
\hline Vibrio proteolyticus & ATCC15338 ${ }^{\mathrm{T}}$ & c & 3 & 1 & 1 & 3 & 1 & 1 \\
\hline Vibrio vulnificus & ATCC27562 $2^{\mathrm{T}}$ & $\mathrm{d}$ & 4 & 1 & 2 & 4 & 1 & 1 \\
\hline Vibrio fluvials & KCTC $2473^{\mathrm{T}}$ & $\mathrm{e}$ & 5 & 1 & 3 & 2 & 1 & 2 \\
\hline Vibrio mimicus & 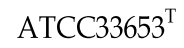 & $\mathrm{f}$ & 6 & 2 & 2 & 5 & 2 & 3 \\
\hline Grimontia hollisae & ATCC $33564^{\mathrm{T}}$ & $\mathrm{g}$ & 7 & 3 & 4 & 6 & 3 & 4 \\
\hline
\end{tabular}

T, Type strain; ${ }^{*}$, Arabian number and alphabetic abbreviation present RFLP fingerprinting types.

A

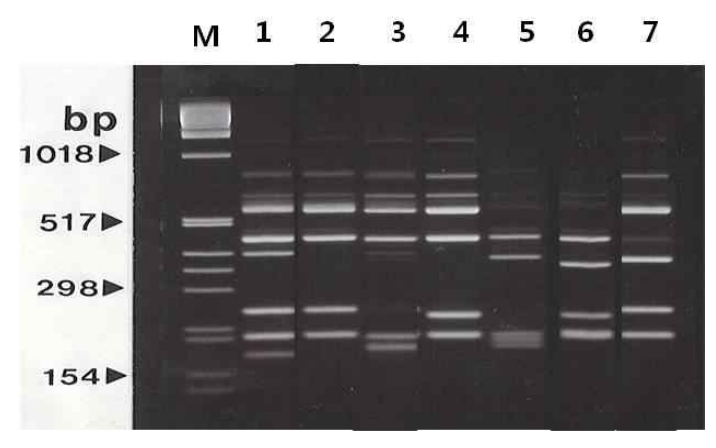

C

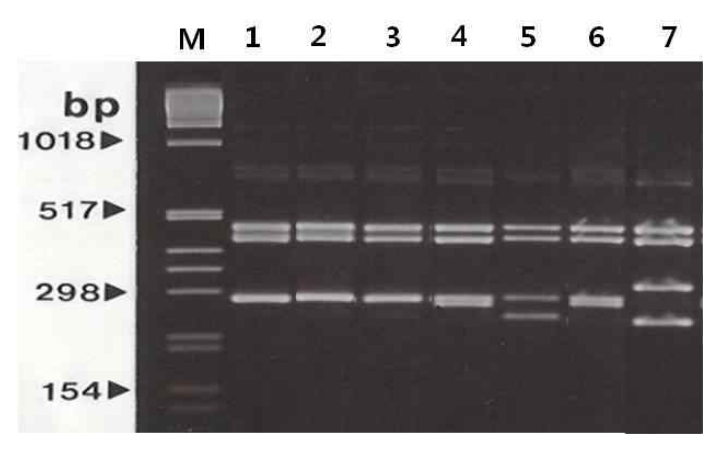

E

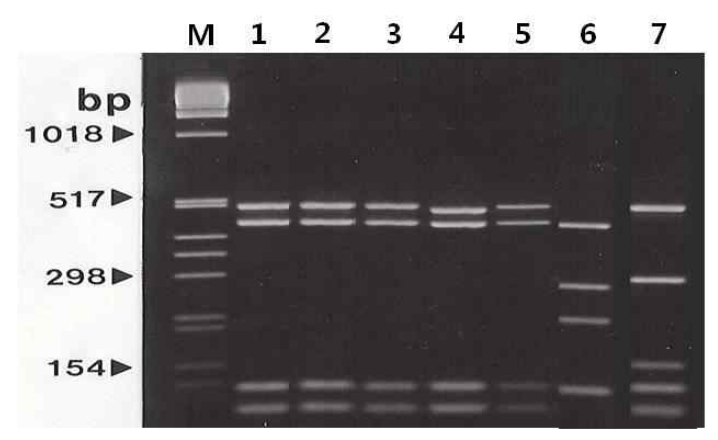

B

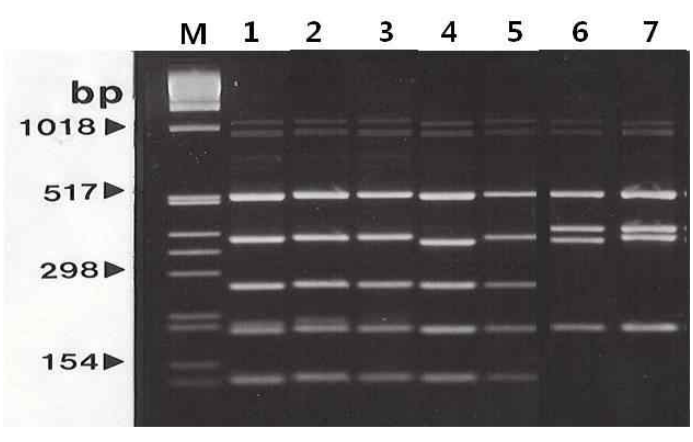

D

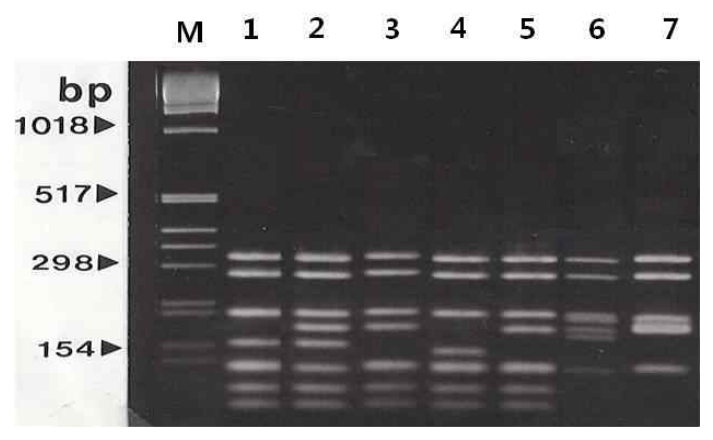

$\mathbf{F}$

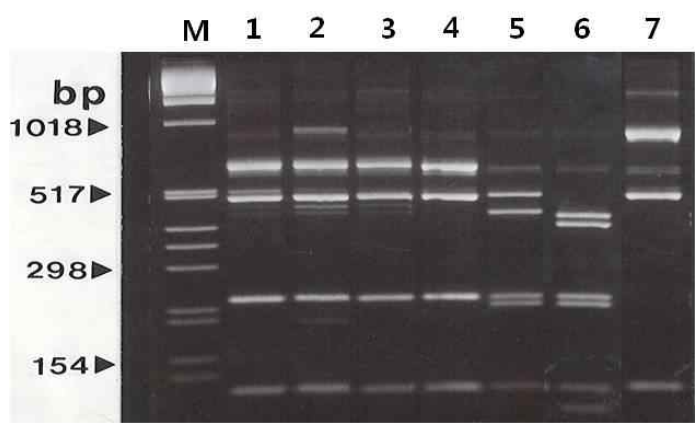

Fig. 1. RFLP fingerprinting patterns of 16S rDNA of the Type strains of Vibrio spp. digested with Alu I (A), Cfo I (B), Dde I (C), Haell(D), MspI (E), and Rsa I (F). Lanes: 1, Vibrio alginolyticus KCTC2472 ${ }^{\mathrm{T}}$; 2, Vibrio parahaemolyticus ATCC17802 ${ }^{\mathrm{T}}$; 3, Vibrio

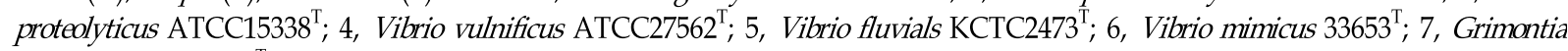
hollisae ATCC $33564^{\mathrm{T}}$. Lane M, size marker (100 bp DNA ladder). 


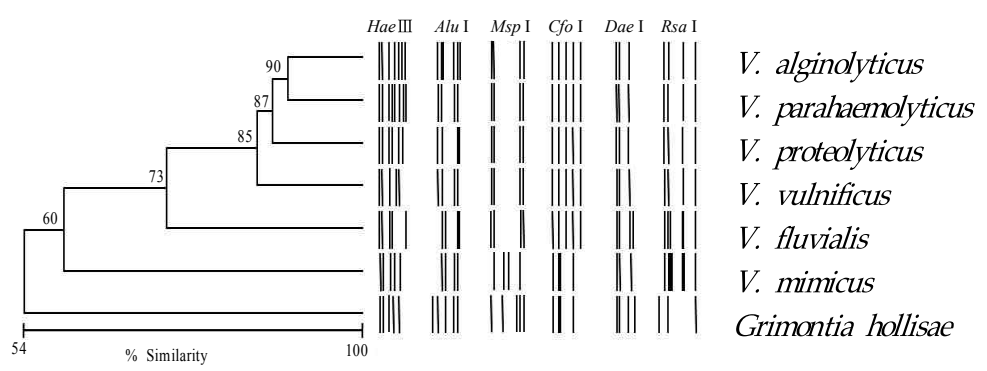

Fig. 2. Dendrogram showing the relationship among the Vibrio spp., based on the $16 \mathrm{~S}$ rDNA-RFLP patterns. The Arabian number indicate similarity $\%$.

종과 cluster를 형성하였다. 반면 참고 균주로 사용한 $G$. holli$s a e^{2}$ 나장ㅇㅇ 먼 유연 관계를 나타내었다(Fig. 2).

\section{고 찰}

Vibrio속의 세균은 주로 수서 환경에 분포하며 사람 혹은 어류 등에 병원성을 나타내는 세균으로 신속한 동정이 매우 중요함에도 불구하고 표현형적, 유전형적 구분이 어려운 경 우가 많아 $[9,14]$ 빠른 동정이 어려운 것으로 알려져 있다. 특 히 Vibrio core group 균주들은 DNA-DNA relatedness 혹 은 $16 \mathrm{~S} \mathrm{rDNA}$ 염기서열에 있어서도 일반적으로 종을 규정 하는 범위 내에 여러 종들이 연속적으로 분포하는 특성을 보이고 있다[4]. 따라서 본 논문에서는 일반적으로 세균 종 의 동정과 계통학적 위치의 고찰에 황금율로 적용되고 있는 $16 \mathrm{~S}$ rRNA gene을 이용하여 Vibrio 종 동정에 대한 $16 \mathrm{~S}$ $\mathrm{rDNA}$ 의 PCR- RFLP방법을 재평가하고자 하였다. 실험에 사용한 Vibrio 균주는 현재 core group 균주로 간주되는 $V$. alginolyticus, V. parahaemolyticus의 2 균주[13]와 이전의 논 문에서 core group으로 간주되었던 V. proteolyticus $[1,2,18]$ 와 V. vulnificus [2]를 포함시켰으며 2003년 Vibrio속에서 Grimontia속으로 옮겨진 G. hollisae [16]를 포함하여 분류학 적 특성에서 매우 유사한 균주들과 분류학적 특성에서 좀더 차이를 나타내는 균주를 대상으로 하여 Vibrio 균주 간의 PFLP type의 차이를 분석하고자 하였다.

6 종의 제한효소를 이용하여 생성된 제한효소패턴(Fig. 1) 에 근거하여 Vibrio 표준 균주들과 G. hollisae의 $16 \mathrm{~S} \mathrm{rDNA}$ 의 RFLP type을 분석한 결과, Vibrio의 RFLP type은 각각 CfoI 와 $M s p$ I 의 경우 2 개, $D d e$ I 와 Rsa I 의 경우 3 개, $H a e l l$, 5 개, $A l u \mathrm{I}$ 를 이용한 경우 6 개의 type을 나타내어(Table 1), 6 종의 제한 효소 중 Vibrio 종의 구분에 HaallI와 $A l u \mathrm{I}$ 이 우수 함을 알 수 있었다. 특히 $A l u \mathrm{I}$ 의 경우 실험한 6 종의 Vibrio 세균 종에 대하여 6 개의 종 특이적 RFLP type을 나타내어 (Table 1, Fig. 1A) Vibrio 종의 동정과 일치함을 알 수 있었다. 반면 CfoI, MspI, DdeI, RsaI 의 경우 종 동정에 대한 변별 력은 낮았으나 6 종류의 효소를 이용한 제한효소패턴을 조합
한 결과 Vibrio 6 종에 대하여 총 6 개의 서로 다른 RFLP type (a-f)으로 구분되어(Table 1), Vibrio 균주의 PCR-RFLP는 본 실험에 사용된 Vibrio 종의 동정에 유용함을 알 수 있었다.

제한효소패턴(Fig. 1)에 근거하여 덴드로그램을 작성한 결 과(Fig. 2) 현재 core group 균주로 간주되는 V. alginolyticus, V. parahaemolyticus는 $90 \%$ 이상의 매우 밀접한 similarity를 나타내었으며 이는 지방산 분석[10], rpoB gene [8] 및 MLSA 방법의 결과[13]와 유사한 결과였다. 이전의 논문에서[1,2,18], $V$. algindyticus, V. parahaemolyticus와 함께 core group으로 간주되었던 V. proteolyticus와 V. vulnificus는 각각 $87 \%, 85 \%$ 이상의 similarity로 cluster를 형성하여 $16 \mathrm{~S}$ rRNA 염기서열 [14] 및 DNA-DNA 상동치[2]에 근거한 결과와 마찬가지로 core group 균주들과 밀접한 유연관계를 나타내었다. 또한 $V$. fluvialis 및 V. mimicus는 실험된 Vibrio종 중에서는 비교적 먼 유연관계를 나타내었으며 이는 다른 표현형적, 유전형적 특징 들에 의한 동정 결과에 상응하는 결과였다 $[9,18]$.

참고 균주로 사용한 G. hollisae의 경우 본 실험에서 사용한 모든 제한 효소에서 Vibrio종과는 분명히 다른 RFLP type을 나타내었으며(Table 1), 덴드로그램(Fig. 2) 상에서 Vibrio종과 는 가장 먼 유연 관계를 나타내어 $16 \mathrm{~S} \mathrm{rDNA}$ 의 PCR- RFLP 방법이 여전히 Vibrio종의 동정에 유용함을 알 수 있었다.

Urakawa 등[19]에 의한 HhaI, DdeI, RsaI, SauBA I, MspI의 4종의 제한 효소를 이용한 Vibrionaceae의 $16 \mathrm{~S}$ rDNA PCR-RFLP 의 결과에 따르면 $V$. alginolyticus, V. parahaemolyticus, V. proteoIyticus, V. vulnificus 의 제한효소패턴이 동일하게 나타났다. 따 라서 Vibrio 균주의 구분에 있어 $16 \mathrm{~S}$ rDNA PCR-RFLP는 변별 력이 매우 낮은 것으로 지적된 바 있으나[18], 본 실험 결과에 따르면 6 종의 Vibrio 균주가 6 개의 RFLP type을 나타내어 종의 구분에 매우 유용하였다. 이러한 연구 결과는 Photobacterium과 Vibrio의 구분에 있어 Hha I을 이용한 PCR-RFLP가 유용하다는 연구 결과[20]와 유사하다.

Vibrio속의 $16 \mathrm{~S}$ rRNA gene은 높은 염기서열 유사성을 갖는 multi copy gene으로 이를 이용한 Vibrio 종의 동정이 용이하지 않음에도 불구하고[6] 본 논문에서 실험된 $16 \mathrm{~S} \mathrm{rDNA}$ 의 PCRRFLP 방법은 Vibrio종의 구분에 있어, 적절한 제한 효소의 선택 
과 결과의 조합에 의해 Vibrio종의 동정에 유용함을 알 수 있었다. $16 \mathrm{~S}$ rRNA gene을 이용하는 경우, 염기서열의 높은 유사성 과 multi copy gene에 기인한 이질성으로 인하여 세균 그룹에 따라 종의 동정이 어려운 경우가 보고되어 온 바[4,18], 정확한 종의 동정을 위하여 MLSA 방법[13,17] 등 특정 유전자를 복수 로 이용하는 방법 등[3]이 권유되고 있다. 이는 $16 \mathrm{~S}$ rRNA gene 과 같이 단일 유전자(single gene)가 아닌 복수 유전자 (multiple gene)를 이용하는 경우이므로 보다 정확한 종 동정 의 결과를 도출할 수 있을 것이다. 그러나 실제적으로 임상에 서와 같이 빠른 동정이 필요한 경우, PCR-RFLP에 의해 $16 \mathrm{~S}$ rRNA gene과 같은 단일 유전자를 대상으로 하여 종의 동정이 가능하다면 PCR-RFLP는 보다 실질적인 Vibrio 종의 동정 및 검출 방법으로 이용할 수 있을 것이다. 나아가 Vibrio 종의 많 은 균주를 대상으로 동정에 유용성을 갖는 제한 효소를 선별 하는 실험을 수행하고 그 결과 특정 Vibrio종의 구분에 유용한 특정 제한 효소를 찾을 수 있다면, 종 특이적(species specific) primer 제작에 이용되는 $16 \mathrm{~S}$ rRNA gene의 신호서열과 같이, 특정 제한 효소를 이용한 PCR- RFLP는 Vibrio 종의 동정에 있어 보다 유용한 방법이 될 수 있을 것이다.

\section{감사의 글}

이 논문은 2011년 한남대학교 학술연구조성비에 의해 수행 되었으며 이에 감사 드립니다.

\section{References}

1. Aznar, R., W. Ludwig., R. I. Amann, and K. H. Schlefer. 1994. Sequence determination of rRNA genes of pathogenic Vibrio species and whole-cell identification of Vibrio vulnificus with rRNA-targeted oligonucleotide probes. Int. J. Syst. Bacteriol. 44, 330-337.

2. Dorsch, M., D. Lane, and E. Stackebrandt. 1992. Toward a phylogeny of the genus Vibrio based on 16S rRNA sequence. Int. J. Syst. Bacteriol. 42, 58-63.

3. Gomez-Gil, B., S. Soto-Rodríguez, A. García-Gasc, A. Roque, T. Vazquez-Juarez, F. L. Thompson, and J. Swings. 2004. Molecular identification of Vibrio harveyi-related isolates associated with diseased aquatic organisms. Microbiol. 150, 1769-1777.

4. Gomez-Gil, B., F. L. Thompson, C. C. Thompson, A. García-Gasca, A. Roque, and J. Swings. 2004. Vibrio hispanicus sp. nov., isolated from Artemia sp. and sea water in Spain. Inc. J. syst. Evol. Microbiol. 54, 261-265.

5. Hernández, G. and J. Olmos. 2003. Molecular identification of pathogenic and nonpathogenic strains of Vibrio harveyi using PCR and RAPD. Appl. Microbiol. Biotechnol. 63, 722-727.

6. Ki, J. S. 2009. Heterogeneity analysis of the $16 \mathrm{~S}$ rRNA gene sequence of the genus Vibria Korean J. Microbid. 45, 430-434.

7. Ki, J. S., R. Zhang, W. Zhang, Y. L. Huang, and P. Y. Qian.
2009. Analysis of RNA polymerase beta subunit $(r p o B)$ gene sequences for the discriminative power of marine Vibrio species. Microb Ecol. 58, 679-691.

8. Kim, D. G., S. H. Ahn, L. H. Kim, K. J. Park, Y. K. Hong, and I. S. Kong. 2008. Application of the rpoS gene for species-specific detection of Vibrio vulnificus by real-time PCR. J. Microbiol. Biotechnol. 18, 1841-1847.

9. Kumar, N. R. and S. Nair. 2007. Vibrio rhizosphaerae sp. nov., a red-pigmented bacterium that antagonizes phytopathogenic bacteria. Inc. J. Syst. Evol. Microbiol. 57, 2241-2246.

10. Lambert, M. A., F. W. Hickman-Brenner, J. J. FarmerIII, and C. W. Moss. 1983. Differentiation of Vibrionaceae species by their cellular fatty acid composition. Int. J. Syst. Bacteriol. 33, 777-792.

11. Lee, J. W., I. J. Jun, H. J. Kwun, K. L. Jang, and J. H. Cha. 2004. Direct identification of Vibrio vulnificus by PCR targeting elastase gene. J. Microbiol. Biotechnol. 14, 284-289.

12. Lerat E, V. Daubin, and N. A. Moran. 2003. From gene trees to organismal phylogeny in prokaryotes: the case of the gammaproteobacteria. PLOS Biol. 1, E19.

13. Pascual, J., M. C. Macián, D. R. Arahal, E. Garay, and M. J. Pujalte. 2010. Multilocus sequence analysis of the central clade of the genus Vibrio by using the 16S rRNA, recA, pyrH, $r p o D, g y r B, r c t B$ and toxR genes. Inc. J. Syst. Evol. Microbiol. 60, 154-165.

14. Pedersen, K., L. Verdonck, B. Austin, D. A. Austin, A. R. Blanch, P. A. D. Grimont, J. Jofre, S. Koblavi, J. L. Larsen, T. Tiainen, M. Vigneulle, and J. Swings. 1998. Taxonomic evidence tha Vibrio carchariae grimes et al. 1985 is a junior synonym of Vibrio harveyi (Johnson and Shunk 1936) Baumann et al. 1981. Int. J. Syst. Bacteriol. 48, 749-758.

15. Rivas, R., P. García-Fraile, P. F. Mateos, E. Martínez-Molina, and E. Velázquez. 2006. Photobacterium halotolerans sp. Nov., isolated from lake Martel in Spain. Inc. J. Syst. Evol. Microbiol. 56, 1067-1071.

16. Thompson, F. L., B. Hoste, K. Vandemeulebroecke, and J. Swings. 2003. Reclassification of Vibrio hollisea as Grimontia hollisae gen. nov., comb. Nov. Inc. J. syst. Evol. Microbiol. 53, 1615-1617.

17. Thompson, F. L., D. Gevers, C. C. Thompson, P. Dawyndt, S. Naser, B. Hoste, C. B. Munn, and J. Swings. 2005. Phylogeny and molecular identification of vibrios on the basis of multilocus sequence analysis. Appl. Microbiol. Biotechnol. 71, 5107-5115.

18. Thompson, F. L., T. Iida, and J. Swings. 2004. Biodiversity of vibrios. Microbiol. Mol. Biol. Rev. 68, 403-431.

19. Urakawa, H., K. Kita-Tsukamoto, and K. Ohwada. 1997. $16 \mathrm{~S}$ rDNA genotyping using PCR/RFLP (restriction fragment length polymorphism) analysis among the family Vibrionaceae. FEMS Microbiol. Lett. 152, 125-132.

20. Urakawa, H., K. Kita-Tsukamoto, and K. Ohwada. 1998. A new approach to separate the genus Photobacterium from Vibrio with RFLP patterns by Hha I digestion of PCR-amplified 16S rDNA. Curr. Microbiol. 36, 171-174.

21. Yeon, S. H., W. J. Jeong, and J. S. Park. 2005. The diversity of culturable organotrophic bacteria from local solar salterns. J. Microbiol. 43, 1-10. 
초록 : PCR-RFLP에 의한 Vibrio core group을 포함한 Vibrio 종의 구분

박진숙*

(한남대학교 생명공학과)

Vibrio속의 core 균주(Vibrio alginolyticus, Vibrio parahaemolyticus)를 포함하여 총 6 종의 Vibrio 균주(V. fluvialis, V. protedyticus, V. vulnificus, V. mimicus)와 Grimontia (Vibrid) hollisae의 $16 \mathrm{~S} \mathrm{rDNA}$ 를 PCR 증폭하여 AluI, CfoI, $D d e$ I, Hae III, MspI, Rsa I의 6 종의 제한효소를 처리 후 RFLP 분석을 수행하였다. 2 종의 core 균주와 V. proteolyticus는 4 종의 제한효소 $(C f o \mathrm{I}, D d e \mathrm{I}, M s p \mathrm{I}, \mathrm{Rsa} \mathrm{I})$ 에서 동일한 제한효소 패턴을 나타내었다. 제한효소의 패턴 의 조합에 의해 6 종의 Vibrio 종은 6 개의 RFLP type으로 구분되었다. 특히 Alu I의 경우, 실험된 6 종의 Vibrio속 에 대하여 각기 다른 6 개의 종 특이적 RFLP type을 나타내었다. 제한효소 패턴에 근거하여 작성한 덴드로그램에 서 Vibrio core group 균주인 V. alginolyticus 와 V. parahaemolyticus는 $90 \%$ 이상의 매우 높은 유사도를 나타내었 다. 반면 Grimontia hollisae는 실험된 모든 제한효소 패턴에서 Vibrio속 세균과는 분명히 구분되는 RFLP type을 나타내었다. 따라서 PCR-RFLP는 제한효소를 적절히 선택한다면 Vibrio 속 세균의 신속한 구분에 여전히 유용하 다. 